\title{
Influence of frost formation and defrosting on the performance of air coolers: standards and dimensionless coefficients for the system designer
}

\author{
C. H. M. Machielsen and H. G. Kerschbaumer* \\ Delft University of Technology, The Netherlands \\ *Refrigeration Engineering Consultant, Seckacherstrasse 26, D-6800 Mannheim 51, FRG \\ Received 21 March 1989
}

\begin{abstract}
Over a period of more than 10 years, fundamental research on frost formation and defrosting behaviour of lamel type air coolers has been pursued at the Delft University of Technology. Many experiments have been performed to support the Dutch Standard for testing air coolers, NEN 1876. This standard gives an objective description of the performance of air coolers under frosting conditions. For the system designer it is very important to judge the average cooling performance and coefficient of performance during the total cycle, consisting of cooling period and defrosting period. For this purpose two dimensionless numbers were derived, which also make it possible to determine, by using computer models, the optimum cooling period before defrosting starts. Finally the use of the developed theories for cost optimization of refrigerating plants and the latest experiences with the Dutch Standard for air coolers, NEN 1876, are discussed.

(Keywords: air cooler; computer model; performance; frost formation; defrosting; testing; standardization)
\end{abstract}

\section{Influence de la formation de givre et du dégivrage sur la performance des refroidisseurs d'air: normalisation et coefficients sans dimensions pour le frigoriste}

\begin{abstract}
Pendant plus de dix ans, des recherches fondamentales sur la formation de givre et le dégivrage des refroidisseurs d'air à ailettes ont été poursuivies à l'Université de Technologie de Delft. On a effectué de nombreuses expériences en vue de l'élaboration de la norme hollandaise NEN 1876 sur l'essai des refroidisseurs d'air. Cette norme fournit une description objective de la performance des refroidisseurs d'air dans des conditions de givrage. Pour l'ingénieur, il est très important d'être en mesure de déterminer la performance moyenne de refroidissement ainsi que le coefficient de performance au cours du cycle entier, c'est-à-dire la période de refroidissement et celle de dégivrage. Dans ce but, deux nombres sans dimensions ont été mis au point; ils permettent de déterminer par ailleurs - au moyen de modèles informatiques - la période de refroidissement optimale avant que le dégivrage ne commence. Enfin, on examine l'application de théories pour l'optimisation des couts des installations frigorifiques ainsi que les toutes dernières expériences effectuées sur les refroidisseurs d'air en fonction de la norme hollandaise NEN 1876.

(Mots clés: refroidissement d'air; programme informatique; cycle thermodynamique; performance; formation de givre; dégivrage)
\end{abstract}

With air coolers, working with a surface temperature below the dew point temperature of the cooled air, water vapour will be subjected to a phase transition from the vapour to the liquid state. In most cases the cooler surface temperature is also below $0^{\circ} \mathrm{C}$ and as a consequence, water vapour will be deposited on the surface of air coolers as a porous layer of ice crystals. The increasing frost layer causes an additional resistance to heat transfer and decreases the air flow rate through the cooler (see Figure 1). For this reason the frost layer has to be removed regularly. Frost formation increases the specific energy consumption, but also defrosting causes costs: the cooler cannot work during defrosting time and the additional (loss) heat supplied to the refrigerated area must be removed again.

At the end of the 1960s and the beginning of the 1970s, in Germany ${ }^{1}$, The Netherlands ${ }^{2}$ and Austria ${ }^{3}$, fundamental research was done on frost formation and defrosting of finned air coolers. Standard methods are available for the testing of non-frosting air coolers, e.g. the American ASHRAE Standard 25-77 'Methods of testing for rating forced convection and natural convection air coolers for refrigeration' (1977) and the

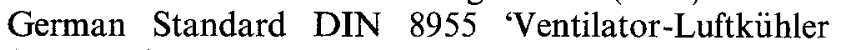
(1976). The Dutch Standard NEN 1876 'Air coolers Determination of the performance of frosted air coolers with forced air circulation' (1979) is entirely directed to the determination of the performance of coolers frosting up during the cooling period and being defrosted afterwards. In the Netherlands a lot of experiments have been performed to support NEN 1876 (Reference 4). The decrease of the momentary refrigerating capacity by frosting and the defrosting losses are fully taken into account. The most important basis for judging is the average performance during the total cycle consisting of cooling period and defrosting period. For an objective comparison of air cooler performance a new quantity, the effective refrigerating capacity, is introduced. By putting 


\section{Nomenclature* \\ a Heat content of cooler and frost layer $\left(\mathrm{J} \mathrm{m}^{-2} \mathrm{~K}^{-1}\right)$ \\ $\bar{a} \quad\left(\partial \dot{Q}_{0} / \partial t_{0}\right)_{0} / \dot{Q}_{00}\left(\mathrm{~K}^{-1}\right)$ \\ $f \quad$ Defrost frequency $\left(\mathrm{s}^{-1}\right)$ \\ $k \quad$ Overall heat transfer coefficient $\left(\mathrm{W} \mathrm{m}^{-2} \mathrm{~K}^{-1}\right)$ \\ $m_{\mathrm{i}} \quad$ Mass of the frost layer $\left(\mathrm{kg} \mathrm{m}^{-2}\right)$ \\ $\Delta_{\mathrm{p}} \quad$ Air side pressure loss by frost formation ( $\left.\mathrm{Pa}\right)$ \\ $P_{\mathrm{v}} \quad$ Fan power $(\mathrm{W})$ \\ $\dot{Q}_{0} \quad$ Cooling capacity $(\mathrm{W})$ \\ $\hat{Q}_{00} \quad$ Nominal cooling capacity (W) \\ $\hat{Q}_{\text {dry }}$ Dry surface cooling capacity (W) \\ $\hat{Q}_{\text {ko }} \quad$ Mean overall capacity (W) \\ $Q_{\mathrm{k}} \quad$ Net mean capacity during cooling period $\tau_{\mathrm{k}}(\mathrm{W})$ \\ $Q_{\mathrm{d}} \quad$ Supplied defrosting heat (J) \\ $Q_{\mathrm{da}}$ Removed heat by thawing water (J) \\ $Q_{\mathrm{ds}} \quad$ Loss heat by defrosting (unprofitable defrosting heat) (J) \\ $\Delta q_{\mathrm{m}} \quad$ Decrease of cooling capacity at frosting $\left(\mathrm{W} \mathrm{m}^{-2}\right.$ ) \\ $q_{\mathrm{H}} \quad$ Supplied defrosting capacity $\left(\mathrm{W} \mathrm{m}^{-2}\right)$ \\ $q_{\mathrm{n}} \quad$ Net cooling capacity during a complete operating cycle $\left(\mathrm{W} \mathrm{m}^{-2}\right)$ \\ $q_{\text {no }} \quad$ Net cooling capacity without frost layer $\left(\mathrm{W} \mathrm{m}^{-2}\right)$ \\ $\Delta q_{\mathrm{v}} \quad$ Rise of fan power by frost formation $\left(\mathrm{W} \mathrm{m}^{-2}\right)$ \\ $t_{0} \quad$ Evaporation temperature $\left({ }^{\circ} \mathrm{C}\right)$}

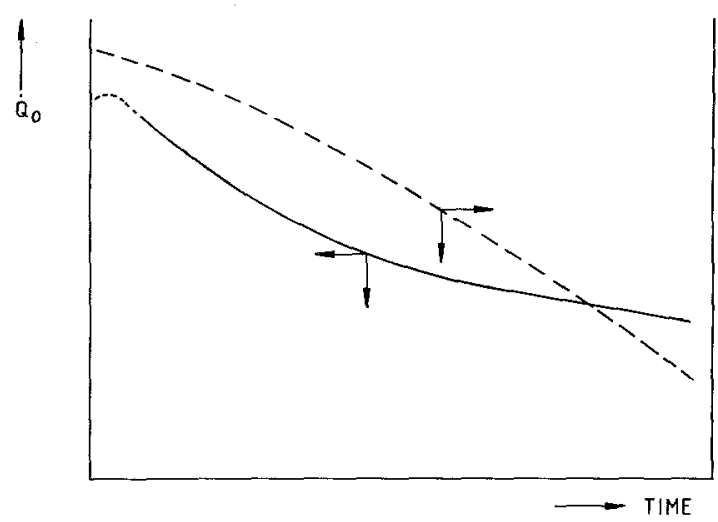

Figure 1 Course of the overall cooling capacity $\left(\dot{Q}_{0}\right)$ and the airflow rate $\left(V_{1}\right)$ during frost formation

Figure 1 Evolution de la puissance frigorifique totale $\left(\hat{Q}_{0}\right)$ et du debit d'air $\left(\mathrm{V}_{1}\right)$ au cours de la formation de givre

this complete cycle in a computer model it is possible to determine at which defrosting frequency the operating costs are minimum and how sharp this minimum is.

This kind of work was also done by Kerschbaumer ${ }^{14}$. First the defrost process itself was described by the term defrost efficiency, then a non-dimensional characteristic $X$ was introduced for the actually available mean net cooling capacity and finally the developed defrost theories were applied for guidelines towards an optimum system.

\section{Frost formation}

Water vapour deposited from the air leads to frost

* The used symbols are partly the same as in the references, which makes a literature study easier
$\Delta t_{0} \quad$ Starting value of inlet temperature difference (K)

$\Delta t_{\mathrm{B}} \quad$ Temperature difference at equilibrium position (K)

$V_{1} \quad$ Fan air flow rate $\left(\mathrm{m}^{3} \mathrm{~s}^{-1}\right)$

$w_{\mathrm{d}} \quad$ Theoretically required defrost heat $\left(\mathrm{J} \mathrm{m}^{-2}\right)$

$w_{\mathrm{L}} \quad$ Loss heat by defrosting $\left(\mathrm{J} \mathrm{m}^{-2}\right)$

$w_{\mathrm{H}} \quad$ Actually consumed defrosting heat $\left(\mathrm{J} \mathrm{m}^{-2}\right)$

$X \quad$ Dimensionless coefficient

$\bar{X} \quad X\left(x_{\mathrm{p}}\right)$, maximum value of $X$

$x \quad$ Time until defrost (s)

$x_{\mathrm{p}} \quad$ Optimum value for maximum capacity (s)

$Y$ Dimensionless coefficient

\section{Greek letters}

$\alpha_{0} \quad$ Heat transfer coefficient of frost layer to air (W m ${ }^{-2} \mathrm{~K}^{-1}$ )

$\alpha \quad$ Specific cost (currency unit $\mathrm{kW}^{-1}$ )

$\eta_{\mathrm{d}} \quad$ Defrost efficiency

$\eta_{\mathrm{v}} \quad$ Fan efficiency

$\tau \quad$ Time (identical to $x$ ) (s)

$\tau_{\mathrm{c}} \quad \tau_{\mathrm{k}}+\tau_{\mathrm{d}}$, total operating period (s)

$\tau_{\mathrm{d}} \quad$ Defrosting period (s)

$\tau_{\mathrm{k}} \quad$ Cooling period (s)

$\vartheta_{0} \quad$ Temperature difference $(\mathrm{K})$

formation and has a great influence on heat transfer with the following positive factors.

1. The latent heat (sublimation of water vapour) increases the heat transfer coefficient at the initial stages of frosting. The influence of the latent heat is included by introduction of the 'sensible heat factor', i.e. the ratio between the total transferred and the sensible heat amount. With this factor it is possible to calculate by approximation the nominal cooling capacity from the 'dry' cooling capacity. Manufacturers often correct with

$\dot{Q}_{00}=1.25 * \dot{Q}_{\mathrm{dry}}$

2. The heat transfer is further improved by the fact that the ice crystals in the beginning lead to an enlargement and more roughness of the surface.

These advantages however are soon followed by the following disadvantages.

3. The poor heat conduction coefficient of the growing frost layer decreases the heat transfer. The evaporation temperature goes down or must be kept constant by a larger cooling surface.

4. The frost formation reduces the air flow rate and enlarges the pressure drop. The air flow rate decreases fast or slowly, depending on the fan characteristic. This can result in too low an exit temperature and an undesired increase of the non-homogeneity of the air condition in the refrigerated area.

\section{Defrosting}

It is obvious that we have to defrost but this also is accompanied by certain disadvantages, as follows.

1. The equilibrium condition (especially in display 
cabinets) is disturbed. Defrosting implies the noncontinuous operation of the air cooler and causes deviations in the desired values of temperature and humidity.

2. The chimney effect, especially with electrical defrosting, can lead to formation of fog and ice at walls, ceiling and on cooled goods.

3. Heating and also expansion of the refrigerated air can lead to high pressure in relation to the pressure outside, and this effect is greater if the fans are started immediately after the defrosting process. This can result in damaging the warehouse and in causing permanent leaks.

\section{The defrosting process}

In 1974 Sanders $^{2}$ traced the defrosting process on film (see Figure 2). In this example a steel air cooler with a fin spacing of $10 \mathrm{~mm}$ was defrosted from the refrigerant side with hot liquid. The frost formation took place at $-20^{\circ} \mathrm{C}$. The defrosting process, starting at the top, can be divided into three phases (see Figure 3).

Phase 1 . The wall and frost layer will be heated up until it reaches a temperature of $0^{\circ} \mathrm{C}$. As soon as the wall reaches $0^{\circ} \mathrm{C}$, ice melts, and the water is immediately absorbed in the frost layer.

Phase 2. The frost layer, which is saturated with water, starts to melt and loosens from the wall creating an air

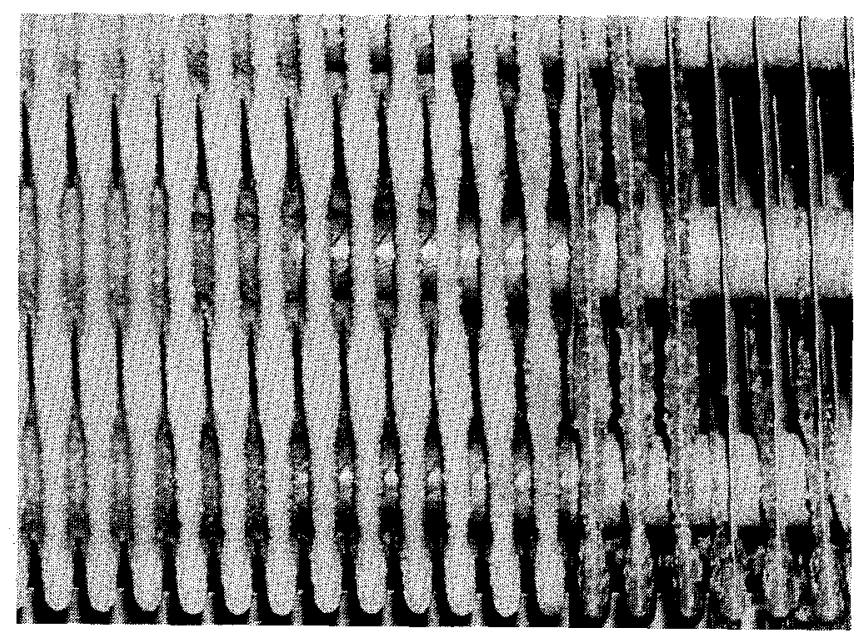

Figure 2 Photograph of an air cooler during defrosting. The defrosting heat is supplied by hot liquid from the refrigerant side of the cooler (from Sanders ${ }^{2}$ )

Figure 2 Photographie d'un refroidisseur d'air cours du dégivrage. La chaleur de dégivrage est fournie par un liquide chaud provenant du côté du frigorigène du refroidisseur (d'après Sanders ${ }^{2}$ ) gap, while a small ice layer is formed on the side of the frost layer which is exposed to the refrigerated area. This ice layer gives mechanical strength to the frost layer.

Phase 3. The air gap becomes larger and the heat flow decreases. At the same time the ice layer grows. When the heat flow by conduction and radiation through the air gap is greater than the heat transported towards the refrigerated area by free convection, the ice layer melts away completely.

\section{Starting point and length of the defrosting period}

Length of cooling period. Several different criteria are used to delimit the operating time until defrost. One can fix limits to measurable quantities, for instance the air pressure drop, the rise of fan power consumption, the thickness of the frost layer or the decrease of the air flow rate. The latter is an interesting measurable quantity because its variation is relatively high. Müller ${ }^{5}$ describes a criterion where the difference between inlet and outlet air temperature is measured. This value is continuously compared with the temperature difference at starting circumstances (dry cooler). A combination of this and the measurement of the air pressure drop gives an indication of the decrease of cooling performance. In practice one often uses a pure time criterion, which will not lead to an optimal economical result.

Length of defrosting period. The defrosting period should be as short as possible. Bäckström ${ }^{6}$ has calculated the defrosting time by a theoretical method. The defrosting time itself is not a good basis for calculating the net available cooling capacity because one also has to take into account the heat lost as a consequence of defrosting.

Kerschbaumer $^{7}$ has found from theory that the value of the quotient

$q_{\mathrm{H}} /\left(\alpha \cdot \Delta t_{\mathrm{B}}\right)$

is important for the defrosting process. A value of one means that the available defrosting heat per unit area balances the loss heat to the refrigerated area per unit area of cooler surface at a temperature difference of $\Delta t_{\mathrm{B}}$. In this situation the cooler reaches the desired equilibrium temperature $t_{\mathrm{B}}$, but does not defrost and therefore works only as a heater. Practical values of this quotient which are not far above unity cause long defrosting periods and high losses.

The defrost efficiency

Only part of the supplied defrosting heat is used for

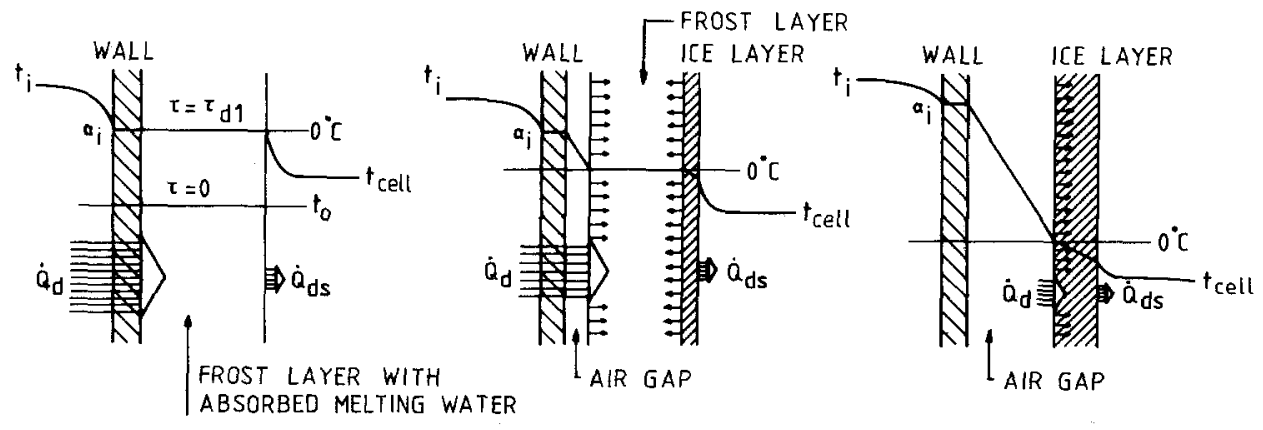

Figure 3 Model of the three phases of the defrosting process when heat is supplied from the refrigerant side

Figure 3 Modèle des trois phases du processus de dégivrage lorsque la chaleur provient du côté du frigorigène 
heating up the frost layer to the melting temperature and for the melting itself. Another part heats the cooler itself and comes as loss heat, especially with electrical heating, in the refrigerated area. The defrost efficiency $\eta_{\mathrm{d}}$ is defined as:

$\eta_{\mathrm{d}}=\frac{\text { melting heat }+ \text { sensible heat of the frost layer }}{\text { supplied defrosting heat }}$

In other words $\eta_{\mathrm{d}}$ is the ratio of the heat $w_{\mathrm{d}}$ that would theoretically be required for the defrost process to the heat $w_{\mathrm{H}}$ actually consumed, i.e. $\eta_{\mathrm{d}}=w_{\mathrm{d}} / w_{\mathrm{H}}$ and the loss $w_{\mathrm{L}}=\left(1-\eta_{\mathrm{d}}\right) \cdot w_{\mathrm{H}}$. Theoretically $\eta_{\mathrm{d}}$ depends on three nondimensional coefficients comprising all essential data. The fairly complex equation for $\eta_{\mathrm{d}}$ is derived in Reference 7 and need not be repeated here. The dominant factor in this equation ruling the effectiveness of the defrost system is the term $q_{\mathrm{H}} /\left(\alpha_{0} \cdot \Delta t_{\mathrm{B}}\right)-1$. The defrost efficiency alone is not enough to give a useful description of the cooling performance of air coolers operating under frosting conditions. For this purpose the Dutch Standard NEN 1876 (Reference 8) introduces the 'effective cooling capacity'.

\section{Standard NEN 1876}

\section{The effective cooling capacity}

The effective cooling capacity of frosted air coolers, in which the defrosting and fan behaviour are taken into account, can be tested for a wide range of standard conditions (see Table l). For air coolers with electrical heating this parameter is a good basis for an objective comparison of the performance, because the heater is normally an integrated part of the cooler. The power and energy quantities one needs to determine the effective cooling capacity are given in Figure 4.

The fan power $P_{v}$ reduces the available net mean cooling capacity:

$\dot{Q}_{\mathrm{k}}=\dot{Q}_{\mathrm{ko}}-P_{\mathrm{v}}$

The effective (net) cooling capacity is defined as follows:

$$
\dot{Q}_{\mathrm{e}}=\left(\dot{Q}_{\mathrm{k}} \cdot \tau_{\mathrm{k}}-Q_{\mathrm{ds}}\right) /\left(\tau_{\kappa}+\tau_{\mathrm{d}}\right)
$$

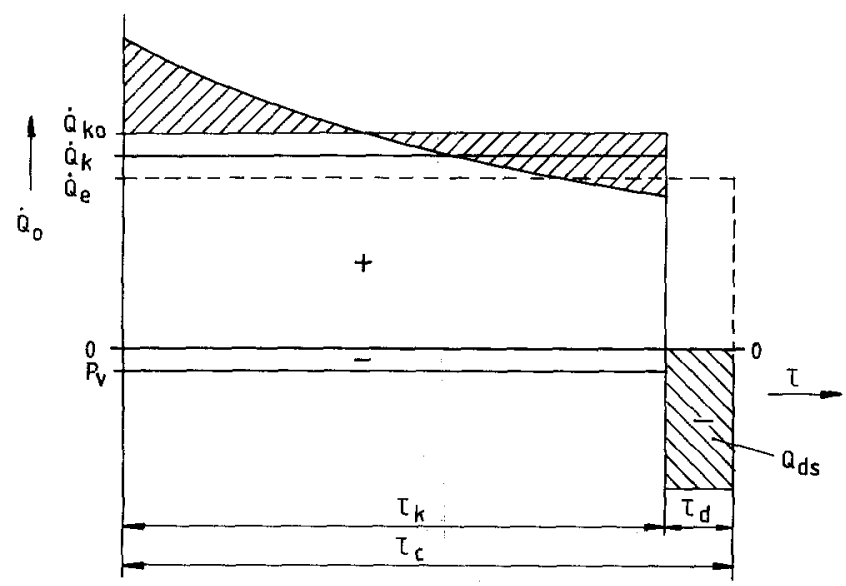

Figure 4 Power and energy quantities for the determination of the effective cooling capacity $\left(\dot{Q}_{\mathrm{e}}\right)$

Figure 4 Quantités d'électricité et d'énergie pour la détermination de la puissance frigorifique effective $\left(\mathrm{Q}_{e}\right)$ with

$Q_{\mathrm{ds}}=Q_{\mathrm{d}}-Q_{\mathrm{da}}$

$\dot{Q}_{\text {oo }}$, the nominal cooling capacity, is an important quantity for selecting the compressor size. This overall cooling capacity is obtained after $0.5 \mathrm{~h}$ from the start of the cooling period. The cooling period is divided into time intervals of $0.5 \mathrm{~h}$. The end of the cooling period is the moment at a multiple of $0.5 \mathrm{~h}$ after the starting point of the cooling period, at least $0.5 \mathrm{~h}$, but less than $1 \mathrm{~h}$ after the moment that the overall cooling capacity is dropped to $85 \%$ of $Q_{\mathrm{o}}$.

During the defrosting period, the air temperature in the test room is kept constant by means of auxiliary air coolers. The defrosting process is ended after two criteria have been met: the cooler surface temperature must be a minimum of $+5^{\circ} \mathrm{C}$ and frost and ice must be completely melted. The removed defrosting heat $Q_{\mathrm{da}}$ is calculated from the cooler surface temperature and the temperature and quantity of the thawing water.

\section{Experimental set-up}

For testing air coolers at standard conditions according to NEN 1876, test chambers with special test equipment for humidity control are needed. The Technical University in Delft uses for this goal a two-compartment test chamber (see Figure 5). In this test chamber air coolers can be tested up to a nominal capacity of $5 \mathrm{~kW}$ at $-10^{\circ} \mathrm{C}$. With this set-up it is also possible to measure the decrease of the air flow rate (not included in NEN 1876).

\section{Application of NEN 1876}

To check whether or not the test method according to NEN 1876 gives comparable and reproducible performance data, a cycle test in different Dutch institutes is now in progress. The first results are satisfactory and a commission should be formed to promote NEN 1876 for international application as a basis for an ISO standard.

In practice NEN 1876 is not used much, although it is the only standard in which frosting and defrosting behaviour is taken into account. With only two manufacturers of air coolers, the Netherlands cannot dictate to the market. Import and export of air coolers dominate the Dutch market. Only when the users of air coolers ask for clearly defined performance data, which are obtained under conditions closely related to practical conditions, will the use of NEN 1876 greatly increase.

\section{Interesting data which are not included in NEN 1876}

The decrease of the air flow rate is determined by the fan characteristic and is, according to Barrow ${ }^{9}$, the main reason for the decrease of the refrigerating capacity. At the end of the test the quantity of thawed water is measured. Together with the cooler surface temperature this gives information about the dehumidification behaviour of the air cooler by means of an enthalpyconcentration diagram ${ }^{10}$.

\section{Optimum time until defrosting}

With a high defrost frequency, the thickness of the frost layer will be thin and the overall heat transfer coefficient will be high. But at the same time the heat losses caused by defrost will increase. Van Male ${ }^{12}$, Kerschbaumer ${ }^{14}$ and 
Table 1 Standard conditions according to Dutch Standard NEN 1876

Tableau 1 Conditions normales d'après la norme hollandaise NEN 1876

(a) Cooling period

Internal conditions

\begin{tabular}{|c|c|c|c|c|c|c|c|c|c|}
\hline \multirow[b]{3}{*}{$\begin{array}{l}\text { Standard } \\
\text { condition } \\
\text { number }\end{array}$} & & & \multicolumn{5}{|c|}{ Primary refrigerant } & & \\
\hline & \multicolumn{2}{|c|}{ External conditions } & \multicolumn{3}{|c|}{ Dry expansion evaporation } & \multicolumn{2}{|c|}{ Pump circulation } & \multicolumn{2}{|c|}{ Coolant } \\
\hline & $\begin{array}{l}\text { Air } \\
\text { temperature } \\
\text { at cooler } \\
\text { inlet } \\
\left({ }^{\circ} \mathrm{C}\right)\end{array}$ & $\begin{array}{l}\text { Relative air } \\
\text { humidity } \\
\text { at cooler } \\
\text { inlet } \\
(\%)\end{array}$ & $\begin{array}{l}\text { Evaporation } \\
\text { temperature } \\
\left({ }^{\circ} \mathrm{C}\right)\end{array}$ & $\begin{array}{l}\text { Liquid } \\
\text { temperature } \\
\text { upstream } \\
\text { restrictor } \\
\left({ }^{\circ} \mathrm{C}\right)\end{array}$ & $\begin{array}{l}\text { Degree of } \\
\text { superheat } \\
\text { (K) }\end{array}$ & $\begin{array}{l}\text { Evaporation } \\
\text { temperature } \\
\left({ }^{\circ} \mathrm{C}\right)\end{array}$ & $\begin{array}{l}\text { Mass flow } \\
\text { rate through } \\
\text { evaporator } \\
\left(\mathrm{kg} \mathrm{s}^{-1}\right)\end{array}$ & $\begin{array}{l}\text { Coolant } \\
\text { inlet } \\
\text { temperature } \\
\left({ }^{\circ} \mathrm{C}\right)\end{array}$ & $\begin{array}{l}\text { Mass flow } \\
\text { rate of the } \\
\text { coolant } \\
\left(\mathrm{kg} \mathrm{s}^{-1}\right)\end{array}$ \\
\hline 1 & +4 & 85 & -6 & 30 & 7 & -6 & & -6 & \\
\hline 2 & 0 & 85 & -10 & 30 & 7 & -10 & To be stated & -10 & To be stated \\
\hline 3 & -18 & 85 & -28 & 30 & 7 & -28 & by the & -28 & by the \\
\hline 4 & -30 & 80 & -40 & 0 & 7 & -40 & manufacturer & -40 & manufacturer \\
\hline 5 & -30 & fog & -40 & 0 & 7 & -40 & & -40 & \\
\hline
\end{tabular}

(b) Defrosting period

\begin{tabular}{|c|c|c|c|c|c|c|}
\hline \multirow[b]{3}{*}{$\begin{array}{l}\text { Standard } \\
\text { condition } \\
\text { number }\end{array}$} & \multirow{2}{*}{\multicolumn{2}{|c|}{ External conditions }} & \multicolumn{4}{|c|}{ Internal conditions } \\
\hline & & & \multicolumn{2}{|c|}{ Defrosting with hot liquid } & \multicolumn{2}{|c|}{ Hot gas defrosting } \\
\hline & $\begin{array}{l}\text { Air temperature } \\
\text { at cooler inlet } \\
\left({ }^{\circ} \mathrm{C}\right)\end{array}$ & $\begin{array}{l}\text { Air temperature } \\
\text { about } 250 \mathrm{~mm} \\
\text { underneath the } \\
\text { cooler } \\
\left({ }^{\circ} \mathrm{C}\right)\end{array}$ & $\begin{array}{l}\text { Inlet temperature } \\
\text { of the hot liquid } \\
\left({ }^{\circ} \mathrm{C}\right)\end{array}$ & $\begin{array}{l}\text { Mass flow rate } \\
\text { of the hot liquid } \\
\left(\mathrm{kg} \mathrm{s}^{-1}\right)\end{array}$ & $\begin{array}{l}\text { Condensation } \\
\text { temperature of } \\
\text { the hot gas in } \\
\text { the cooler at } \\
\text { pressure } p_{\mathrm{n}} \\
\left({ }^{\circ} \mathrm{C}\right)\end{array}$ & $\begin{array}{l}\text { Evaporation } \\
\text { temperature of the } \\
\text { hot gas upstream } \\
\text { the back pressure } \\
\text { valve at pressure } p_{\mathrm{g}} \\
\left({ }^{\circ} \mathrm{C}\right)\end{array}$ \\
\hline 1 & +4 & - & & & & - \\
\hline 2 & - & 0 & To be stated & To be stated & To be stated & +25 \\
\hline 3 & - & -18 & by the & by the & by the & +25 \\
\hline 4 & - & -30 & manufacturer & manufacturer & manufacturer & +25 \\
\hline 5 & - & -30 & & & & +25 \\
\hline
\end{tabular}

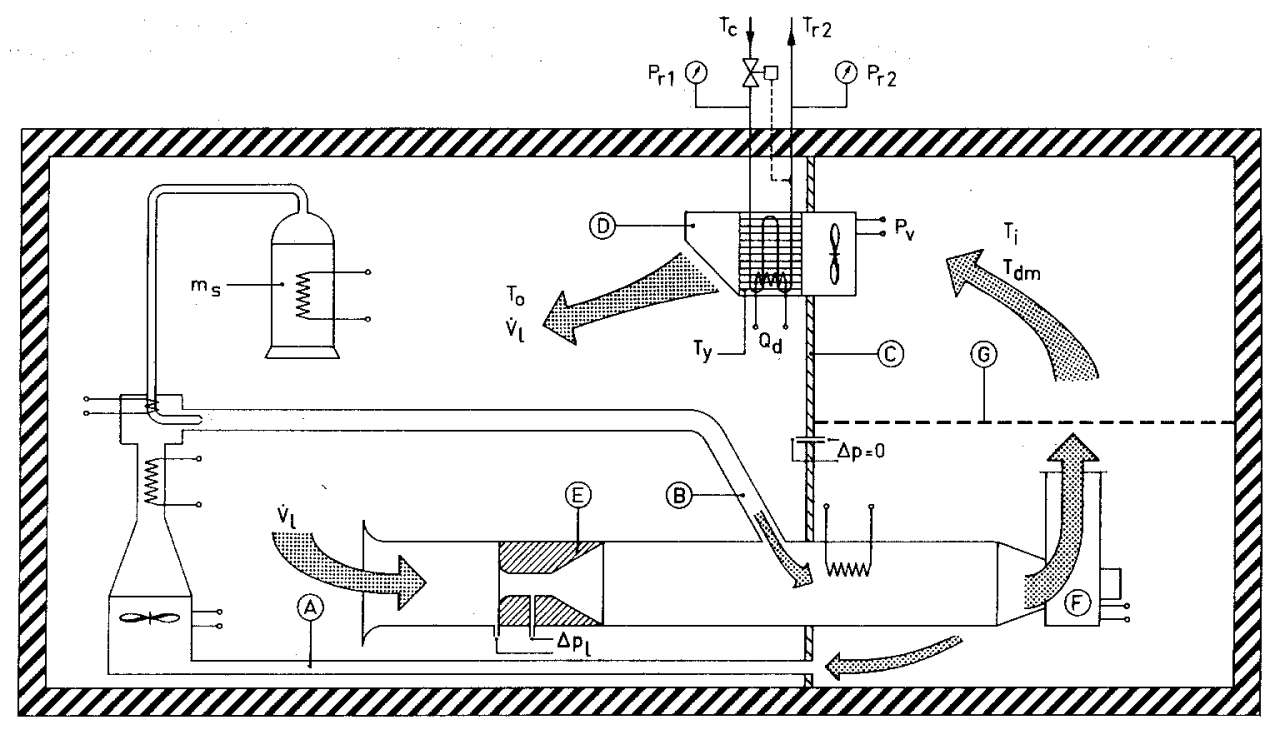

Figure 5 Schematic view of the two-compartment test chamber for air coolers at the Delft University of Technology. A, Suction line air conditioning unit; B, inlet line for heated and humidified air; $C$, partition in which the air cooler is situated; D, air cooler (evaporator); E, measuring device for the air flow rate; $\mathrm{F}$, adjustable auxiliary fan; $\mathrm{G}$, perforated wall for uniform air distribution

Figure 5 Schéma d'une chambre d'essai à deux compartiments pour les refroidisseurs d'air à l'Université de Technologie de Delft. A, Groupe de conditionnement d'air sur la conduite d'aspiration; $B$, Conduite d'entrée pour l'aire chauffé; $C$, Séparation dans laquelle le refroidisseur d'air est situé; $D$, Refroidisseur d'air (évaporateur); $E$, Dispositif de mesure du débit d'air; $F$, Ventilateur auxiliaire ajustable; $G$, Paroi perforée pour la répartition uniforme d'air 


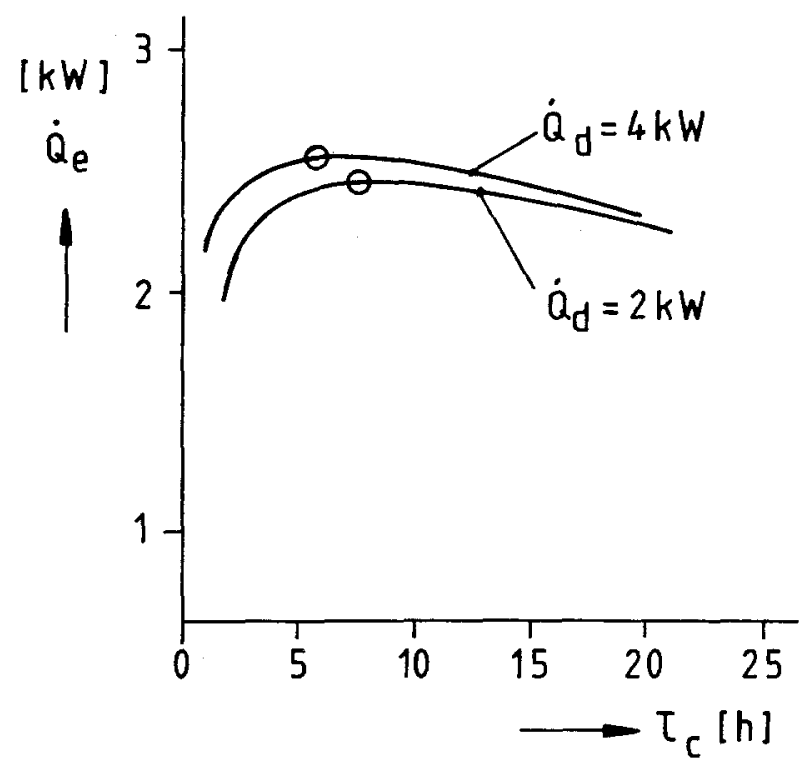

Figure 6 Optimal cycle time for hot gas defrosting (from Van Male ${ }^{8}$ ); $\tau_{\mathrm{c}}=\tau_{\mathrm{k}}+\tau_{\mathrm{d}}=1 / f ; \eta_{\mathrm{d}}=50 \%$; standard condition Nr. 2, from NEN 1876 Figure 6 Temps optimal du cycle pour le dégivrage par gaz chaud (d'après Van Male); $\tau_{c}=\tau_{k}+\tau_{d}=1 / f ; \eta_{d}=50 \%$. Condition normalisée $n^{\circ} 2$ de la norme NEN 1876

Bonte $^{11}$ have investigated the defrost frequency at which the operating costs of the refrigeration plant are minimum and the influence of the defrost frequency on the course of this minimum, for instance how sharp the minimum is. As a first indication it is interesting to know at which defrost frequency the effective cooling capacity is a maximum. Figure 6 shows the results of Van Male ${ }^{12}$. From these curves it is obvious that the effective cooling capacity decreases and the optimum cycle period becomes longer when the installed defrosting power is lower. The steep descent at the left is caused by the big influence of heat loss at frequent defrosting.

The objective of Kerschbaumer's work ${ }^{3,13}$ was to investigate the critical factors determining capacity, energy-consumption and operational costs. Because of space limitation the equations cannot be repeated here but they can be found in Reference 14. These were embranced by three non-dimensional ratios:

- $\Delta q_{\mathrm{m}}(x) / q_{\text {no }}$ is the ratio of the mean net capacity loss during the cooling period $x$ and the initial net capacity;

- $w_{\mathrm{L}}(x) /\left(x \cdot q_{\mathrm{no}}\right)$ is the ratio of the loss energy $w_{\mathrm{L}}(x)$ transferred into the refrigerated space during defrosting and the reference energy $x \cdot q_{\mathrm{no}}$;

- $\tau_{\mathrm{d}}(x) / x$ is the ratio of the defrost time and of the operating time until the start of the defrost period.

They were then combined with the defrost loss $w_{\mathrm{L}}$ and defrost time $\tau_{\mathrm{d}}$, to produce a non-dimensional characteristic $X . X$ is defined as ratio of the actually available mean net cooling capacity $q_{\mathrm{n}}$ during a complete operating cycle (cooling period $x$ plus defrost period $\tau_{\mathrm{d}}$ ) to the starting value of the net cooling capacity under frost free conditions $q_{\mathrm{no}}$.

$X(x)=q_{\mathrm{n}} / q_{\mathrm{no}}=\left(1-\frac{\Delta q_{\mathrm{m}}(x)}{q_{\mathrm{no}}}-\frac{w_{\mathrm{L}}(x)}{x \cdot q_{\mathrm{no}}}\right) /\left(1+\frac{\tau_{\mathrm{d}}(x)}{x}\right)$

$X$ represents the influence of the following parameters:
- time dependent functions for cooler heat transfer $(k)$ and air side pressure drop $(\Delta p)$ due to frost build-up;

- fan data (volume flow $V$, pressure difference $\Delta p$, power $q_{\mathrm{F}}$, efficiency $\eta_{\mathrm{F}}$ );

- design value of the difference between entering air temperature and evaporating saturation temperature $\vartheta_{0}$

- sensitivity of the refrigeration capacity of the condensing unit to changes in evaporator temperature at the starting point $\left(\partial Q_{0} / \partial t_{0}\right)_{0}=\bar{a}$;

- the defrost process as described by the defrost efficiency $\eta_{\mathrm{d}}$;

- system operation/control, i.e. the duration $x$ of the cooling period until defrosting is initiated.

$X(x)$ strongly varies with $x$. After an optimal interval $x_{\mathrm{p}}$ ( $p$ means performance) $X$ reaches the maximum $\bar{X}$. In similar fashion a variable $Y(x)$ was derived as a measure for the mean energy input for the complete operating cycle. The minimum for $Y(x), \bar{Y}$, is reached after an interval $x_{\mathrm{e}}$ (e means efficiency). Typical curves for $X(x)$ and $Y(x)$ are shown in Figure 7. It should be stressed that $X(x)$ and $Y(x)$ do not merely describe the cooler itself but rather the cooler operating in a specified system. A high value of the defrost efficiency was assumed for curves 1 and 3 and low value for curves 2 and 4 . A high rate of ice build-up was assumed for curves 1 and 2 and an extremely high rate for curves 3 and 4 . Further assumptions were an only small decrease of air flow and no variation of evaporator temperature. In Reference 13 the results obtained were described as follows: "Data for $\bar{X}$ can be easily obtained from tests by operating the evaporator

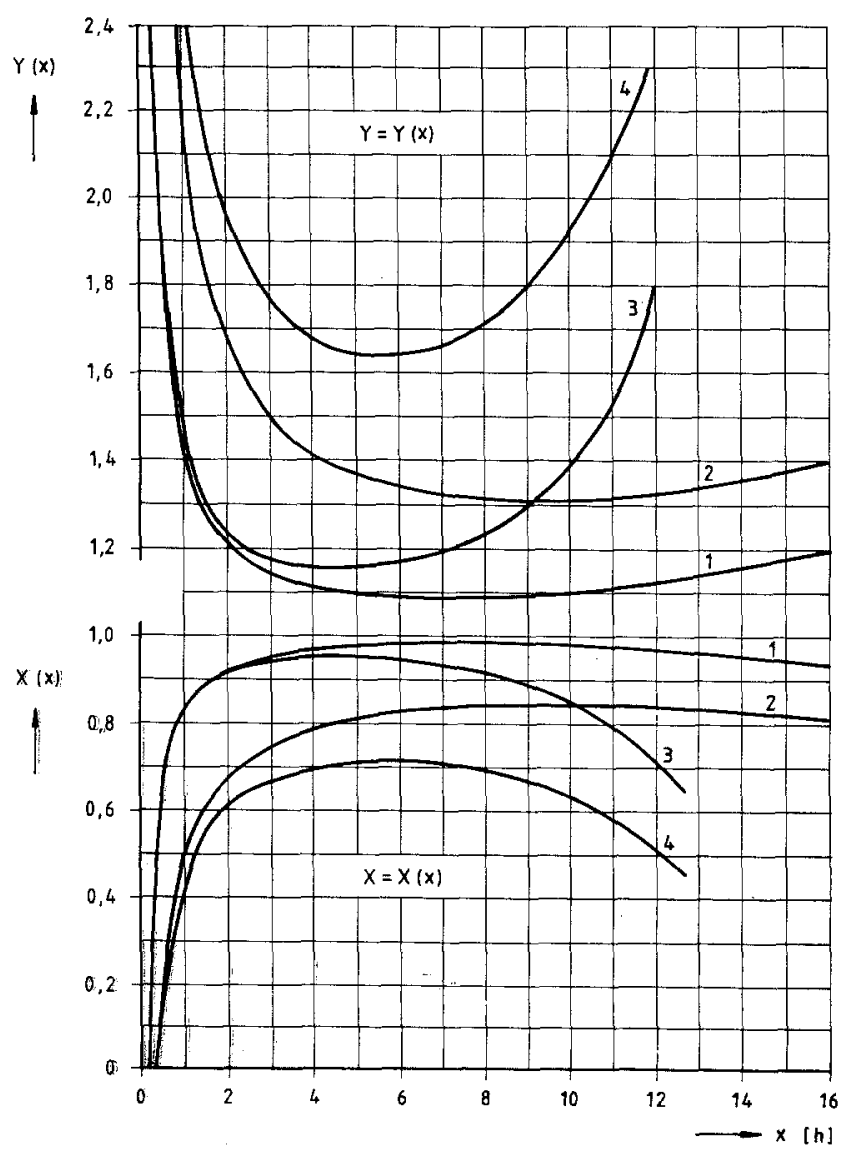

Figure 7 Scope of non-dimensional characteristic data $X$ and $Y$ Frgure 7 Pontée des résultats caractéristiques sans dimensions $\mathrm{X}$ et $\mathrm{Y}$ 
under investigation within a test chamber. This would only require to maintain typical freezer conditions in the chamber, to operate the system along a load line representing a certain $\left(\partial Q_{0} / \partial t_{0}\right)_{0}$-value and to defrost the cooler after intervals giving the highest mean performance. Data $\bar{X}$ together with the rating conditions on which they are based would be a valuable addition to the published air cooler performance data. This would give the design engineer not only information about the initial capacity but also about the actual mean net capacity for continuous operation". This statement was published in 1971 at the IIR Congress in Washington DC. In fact this was a plea to develop an international standard for testing of air coolers under frosting conditions.

\section{Guidelines for designing refrigeration systems with minimum total costs}

The flow chart shown in Figure 8 illustrates all essential parameters and the available options for optimization of the overall refrigeration system. To demonstrate the crucial effect of $\bar{X}$ an approximate function for the total annual costs is derived:

$F(\alpha) \approx(A \cdot \alpha+B) / \bar{X}(\alpha)$

This equation shows the total costs and the characteristic $\bar{X}$ as functions of a variable specific cost coefficient $\alpha$, with $A$ and $B$ being constants. A qualitative interpretation of this equation is attempted in Figure 9. The scope of the $\alpha$ curve is based on the consideration that quite high $X$ values, e.g. up to $\bar{X}=0.9$, can be reached with little additional cost. Only if one would attempt to achieve $\bar{X}$ values approaching 1 will the costs increase dramatically.
The $\alpha$-curve was arbitrarily limited at $\alpha=2 \alpha_{\text {min }}$. It would make no sense to double the costs to get $\bar{X}=1$. On the other hand $\bar{X}=1$ must be in very close reach with such an expensive system. The important section of the $\alpha$-curve is the moderately ascending left part. From it the following guideline for an 'optimum system' can be deduced: design for highest possible $\bar{X}$ with minimum increase of specific

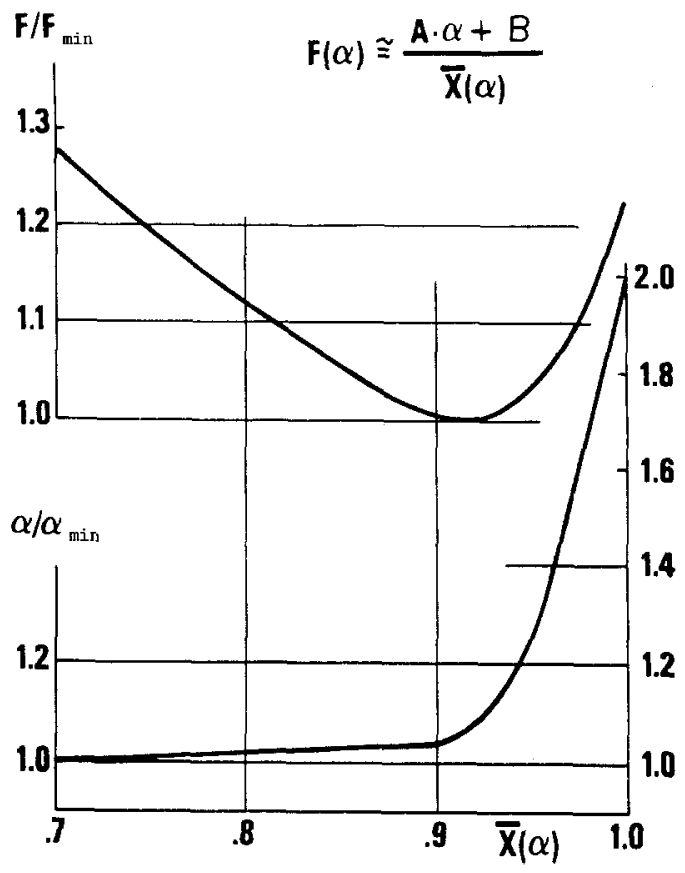

Figure 9 Qualitative influence of the coefficient $X(\alpha)$ on the total annual costs $F(\alpha)$ of the refrigeration plant

Figure 9 Influence qualitative du coefficient $\mathrm{X}(\alpha)$ sur les coûts totaux annuels $\mathrm{F}(\alpha)$ de l'installation frigorifique

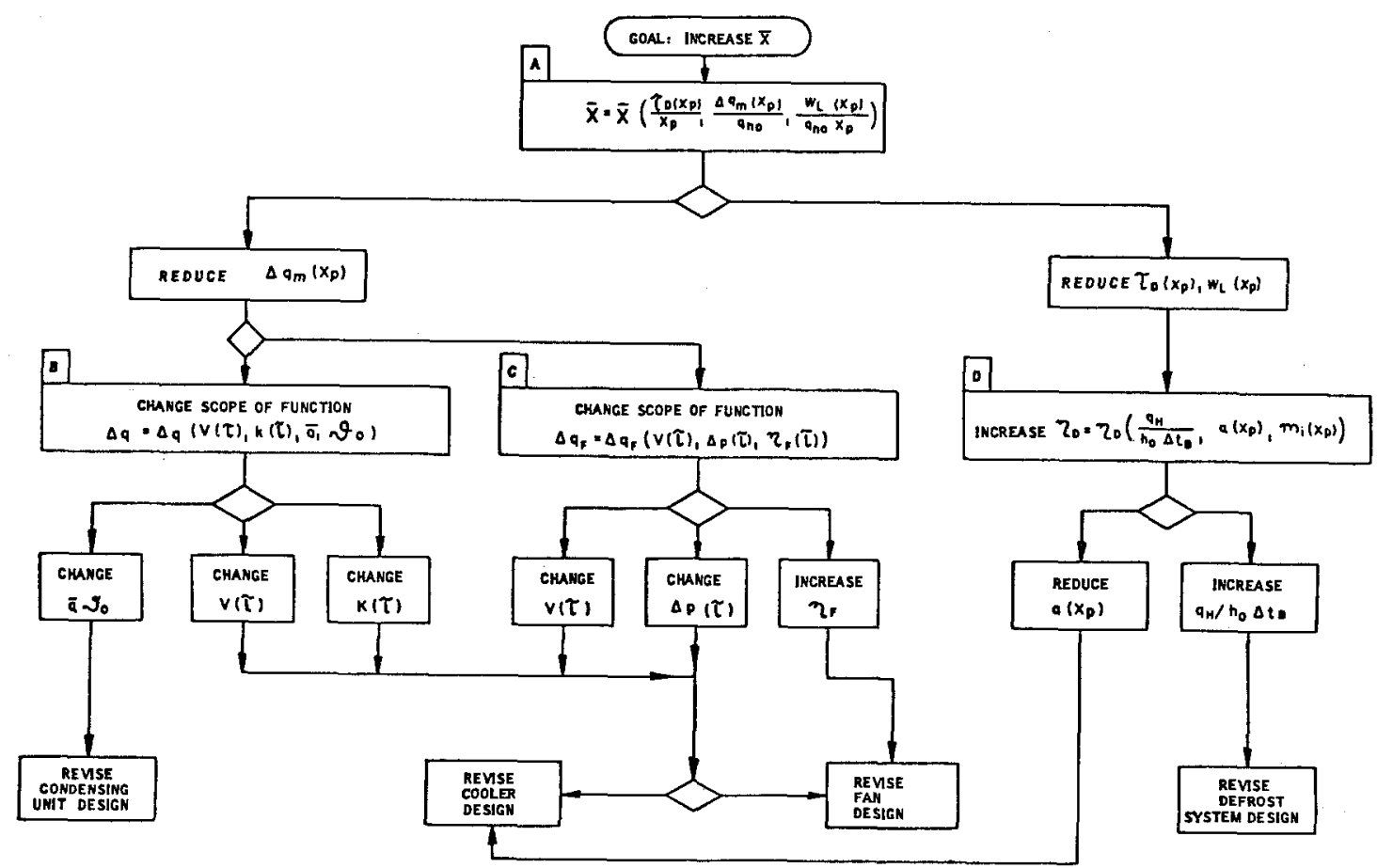

Figure 8 Flowchart showing means to increase $X$. A, Model of overall system; B, model of cooler operation; C, model of fan operation; D, model of defrost process

Figure 8 Organigramme montrant le moyen d'augmenter X. A, modèle du système complet; $B$, modèle du fonctionnement du refroidisseur; $C$, modèle du fonctionnement du ventilateur; $D$, modèle du procédé de dégivrage 
initial costs $\alpha$ and herewith achieve a significant minimum of the total costs $F(\alpha)$.

In Reference 14 the subject is summarized with the following conclusions.

1. The initial costs of a refrigeration system (operating under frost build-up conditions) are exactly proportional to $1 / \bar{X}$ and the total annual costs are approximately proportional to $1 / \bar{X}$.

2. The defrost system (characterized by the defrost efficiency $\eta_{\mathrm{d}}$ ) has a dominating influence on $\bar{X}$.

3. A very high $\vec{X}$ can be achieved by proper application of defrost theories.

4. Using good design techniques, high $\eta_{\mathrm{d}}$ and $\bar{X}$ can be accomplished without increasing the initial costs.

5. A highly effective defrost system is the first step in any attempt for optimization.

6. Without major problems 'close to perfect' defrost systems can be designed yielding very short defrost periods $\tau_{d}$ and low losses $w_{L}$. This will allow comparatively short optimal operating times until defrost $x_{p}$ and will reduce the significance of the time dependent decrease of the cooler performance.

\section{Conclusions}

By using the effective refrigerating capacity and/or the non-dimensional characteristic data $\bar{X}$, it is possible to design on optimal balanced system. With currently available methods and tools, especially in the field of microelectronics, improvements can be achieved in the design of air coolers, which frost and defrost uniformly and the design of defrosting systems, which start when it is necessary (on demand) and stop the defrosting processes when the last ice particle is melted.

The application of Standard NEN 1876 can stimulate the introduction of these improvements. But also initiatives from the users are required. This cooperation ${ }^{15}$ is a good example of the synergism and uniform direction of laboratory research on one side and systematically analysed field experience on the other side. The need for and the usefulness of Standard NEN 1876 are confirmed.

\section{References}

1 Lotz, H. Warme- und Stoffaustauschvorgänge in bereifenden Lamellenrippen-Luftkuhlern in Zusammenhang mit deren Betriebsverhalten Dissertation TU Aachen (1968)

2 Sanders, C. Th. Frost formation (The influence of frost formation and defrosting on the performance of air coolers) Dissertation TU Delft (1974)

3 Kerschbaumer, H. G. Analyse des Einflusses der Bereifung und der Abtauung von Luftkühlern auf Leistung und Energieverbrauch von Kälteanlagen Dissertation TU Wien (1971)

4 NEN 1876, Luchtkoelers (Bepaling van de gebruikseigenschappen van berijpende luchtkoelers met gedwongen luchtcirculatie), NNI Delft (1979)

5 Müller, D. Ein neues Konzept für die Enteisung von Kühlanlagen Kälte (1970) (2)

6 Bäckström, M., Emblick, E. Kältetechnik G. Braun, Karlsruhe (1953)

7 Kerschbaumer, H. G. Probleme der Heissgasabtauung bei Frigenanlagen mit Expansionsventilbetrieb Kälte (1969) (11) 577-584; (1969) (12) 641-646; (1970) (2) 67-72

8 Machielsen, C. H. M. Bereifung und Abtauung von Luftkühlern: Theoretische Gesichtspunkte, Versuchsergebnisse, Standard NEN 1876, Systemoptimieurung, Proc DKV Meeting, Köln DKV, Stuttgart, FRG (1987) 14 341-360

9 Barrow, H. A note on frosting of heat pump evaporator surfaces Heat Recovery Syst (1985) 5(3) 195-201

10 Vahl, L. De luchtvochtigheid in de gekoelde ruimte Koeltechniek (1981) 74 27-32

11 Machielsen, C. H. M. Theoretische gezichtspunten van het ontdooien van luchtkoelers (onderzoek bij de TH-Delft) Koeltechniek (1985) 78 126-131

12 van Male, J. De optimale frequentie voor de ontdooiing van luchtkoelers met persgas Koeltechniek (1980) 73 96-102

13 Kerschbaumer, H. G. Analysis of the influence of frost formation on evaporators and of the defrost cycles on the performance and power consumption of refrigeration systems Proc 13th IIR Congress Washington DC, USA (1971) paper 3.11

14 Kerschbaumer, H. G. Reduction of size and energy consumption of refrigeration plants by proper application of defrost theories Proc IIR Meeting Tokyo, Japan (1974) Communication B2

15 Kerschbaumer, H. G., Machielsen, C. H. M. Theoretische gezichtspunten van het ontdooien van luchtkoelers (Addendum: Probleembenadering vanuit "een koeltechnisch ontwerper) Koeltechniek (1980) 80 18-20 